\title{
Morphoquantitative study of the submucous plexus (of Meissner) of the jejunum-ileum of young and old guinea pigs
}

\author{
Marcelo César Zanesco ${ }^{1}$, Romeu Rodrigues de Souza²
}

\begin{abstract}
Objective: To study the aging of submucous plexus of the small intestine (jejunum-ileum) of the guinea pigs from the quantitative, structural and ultrastructural perspective. Method: Chemical preparations of membrane of the jejunum-ileum of old and young animals with the use of light and electronic microscope. Results: The ganglia of young animals presented between 1 and 56 neurons and the old animals presented from 1 to 30 neurons. The mean density of the ganglia by $\mathrm{cm}^{2}$ in the young jejunum-ileum was of $551 \pm 36.89$ and in the old one $413 \pm 11.86$. The density of the neurons was $5011 \pm 291.11$ neurons $/ \mathrm{cm}^{2}$ average in young animals and $2918 \pm 120.70$ neurons $/ \mathrm{cm}^{2}$ in the old ones. The size of the neurons varied in both age groups. The collagen fibers in the ganglia of old animals they were condensed. Degenerated mitochondrias in the interior of the cell were frequent in the old animals. Conclusion: In submucous plexus of the jejunum-ileum there is a loss of $38 \%$ of the neurons with aging.
\end{abstract}

Key words: aging, morphometrics, submucous plexus, jejunum-ileum, guinea pig.

Estudo morfoquantitativo do plexo submucoso (de Meissner) do jejuno-íleo de cobaias jovens e velhas

\section{RESUMO}

Objetivo: Estudar o envelhecimento do plexo submucoso do intestino delgado (jejunoíleo) das cobaias do ponto de vista quantitativo, estrutural e ultra-estrutural. Método: Preparados de membrana do jejuno-íleo de animais jovens e velhos com a utilização de microscopia de luz e eletrônica. Resultados: Os gânglios de animais jovens apresentaram entre 1 e 56 neurônios e os animais velhos apresentaram de 1 a 30 neurônios. A densidade média dos gânglios por $\mathrm{cm}^{2}$ no jejuno-íleo jovem foi de $551 \pm 36,89$ e no velho foi de $413 \pm 11,86$. A densidade dos neurônios foi de $5011 \pm 291,11$ neurônios $/ \mathrm{cm}^{2}$ em média nos animais jovens e 2918 $\pm 120,70$ neurônios $/ \mathrm{cm}^{2}$ nos velhos. $O$ tamanho dos neurônios variou em ambos os grupos etários. As fibras colágenas nos gânglios de animais velhos estavam mais condensadas. Mitocôndrias degeneradas no interior da célula foram freqüentes nos animais velhos. Conclusão: No plexo submucoso do jejuno-íleo há uma perda de $38 \%$ dos neurônios com o envelhecimento.

Palavras-chave: envelhecimento, morfometria, plexo submucoso, jejuno-íleo, cobaia.

\section{Correspondence}

Marcelo César Zanesco

University São Francisco

Alameda Suíça 32

12919-170 Bragança Paulista SP - Brasil

E-mail: marzane@uol.com.br

Received 15 February 2010

Received in final form 21 September 2010

Accepted 28 September 2010
Aging of the nervous system provokes loss of neurons, both in the somatic and the autonomic nervous system ${ }^{1}$. The neurons of the autonomic nervous system that innervate the digestive tract, heart, trachea and urinary bladder are located on the wall of the organs. These neurons integrate collective networks of the intrinsic plexuses. In the digestive tract there are two plexuses, one located in the muscular layer (my-

${ }^{1}$ Department of Anatomy, Institute of Biomedical Sciences of the University of São Paulo, São Paulo SP, Brazil; ${ }^{2}$ Department of Anatomy, São Judas Tadeu University, São Paulo SP, Brazil. 
enteric plexus) and the other one in the submucous layer (submucous plexus). Together, these two plexuses integrate enteric nervous system. Studies on the aging of the myenteric plexus of the different segments of the digestive tract have been made since a long time ago $\mathrm{a}^{2-5}$. However, nothing has been mentioned in the literature on the aging of the submucous plexus of the small intestine. The submucous plexus acts in the control of the contractile activity of the smooth musculature of the villi, in the transport of ions through the mucous and in the secretory activity of glandular cells ${ }^{6-8}$. Therefore, this work presents a study on the aging of the submucous plexus (of Meissner) of the jejunum-ileum of the guinea pig, particularly from the morphoquantitative point of view.

\section{METHOD}

Twenty two animals were used for this study. Six young male guinea pigs (around 5 months old) and six old ones (around 25 months old) were used. The animals were sacrificed with an overdose of ether. After opening the abdominal cavity and removing the small intestine, four equidistant segments of the jejunum-ileum were obtained from the duodenojejunal transition up to the cecum. Each segment was opened lengthwise along the mesenterial border and washed with a fixative solution ${ }^{9}$. Subsequently, a $0.4 \mathrm{~cm}^{2}$ circular fragment was removed from each segment, from which the mucous was taken out.

The fragments remained in a fixative solution for 18 hours, after which they were transferred to the Giemsa staining solution ${ }^{5}$ where they remained for 24 hours. After being dehydrated in a series of absolute alcohol and diaphanized in a series of xylol, the pieces were dissected under a stereoscopic microscope $(10 \times$ and $40 \times)$. Then the muscular layers were removed, keeping only the submucous layer, which was set up between sheet and small synthetic resin sheet, without microtomy, because the tissue was thick enough for the analysis. The neurons and ganglions of the submucous plexus were counted in a light microscope, in the fragments of each segment of the jejunum-ileum, with a $10 \times$ objective and a $40 \times$ objective. All the ganglions and neurons in each $0.4 \mathrm{~cm}^{2}$ of the membrane were counted, beginning with the upper left angle and scanning all the section in zig-zag. The neurons were also counted independently and in pairs. These were considered as ganglions for the sake of the calculation (regardless being isolated or not, they are part of ganglions). The densities of the ganglions and the neurons were calculated (number of ganglions and neurons per $\mathrm{cm}^{2}$ ) from the results obtained from the counting and the area of each section $\left(0.4 \mathrm{~cm}^{2}\right)$ already known, besides the average number of neurons per ganglion respectively and the corresponding standard deviations. The area of the maximum cellular profile of the neurons was measured in
50 neurons obtained at random from each fragment, using the computerized image (KS-300, ZEISS) for analysis. The averages obtained were statistically compared by the t Student test. The significant level employed was $\mathrm{P}<0.05$.

Six animals ( 3 young and 3 old) were used for the histological analysis of the plexus structure. After opening the abdominal cavity, the small intestine was removed, washed with saline solution and subsequently placed in a fixative Bouin solution for 24 hours. Then $2 \mathrm{~cm}$ long fragments were removed from the jejunum-ileum region of each animal. After including the blocks in paraffin, they were submitted to $5 \mu \mathrm{m}$ thick histological sections, transversally and lengthwise to the axis of the digestive tract. The sections were alternately stained by HematoxilineEosine and by Picrossirius ${ }^{9,10}$.

Four animals ( 2 young and 2 old) were used for the study of the plexus ultrastructure. After opening the abdominal cavity and removing the small intestine, fragments of the jejunum-ileum were placed in a glutaraldeid fixative solution at $3 \%$, in a phosphate buffer solution (0.1 M (pH 7.3) for 2 hours and fixed in osmium tetroxide. Immediately after, the pieces were dehydrated in alcohol, and included in Araldite resin. Thick sections were made and stained with toluidine blue. Afterwards some small cuts were made, also in the microtome, which after being stained with citrate of lead and acetate of uranila, they were placed under metal mesh of mesch 200 and examined with the Jeol transmission electronic microscope (ICB-USP).

The total area of the jejunum-ileum of both age groups was obtained by tracing, with a black pencil, the small intestine, from the transition duodenal-jejunal to the ileocecal transition area, placed on drafting paper, supported by negatoscope, and, later measured with a planimeter (OTT-30).

Ethical committee for animal research (CEEA): Protocol n 072/99 about "Morfoquantitative study on the submucous plexus (Meissner) of the jejunum-ileum in aging guinea-pig" with the Ethical Principles in Animal Research adopted by Brazilian College of Animal Experimentation (COBEA) and was approved by the Biomedical Sciences Institute/USP - Ethical Committee for animal research (CEEA) in 07/10/99 meeting.

\section{RESULTS \\ Histological analysis}

In both groups of animals (young and old) the submucous plexus appeared in a similar manner: made up of small, elongated, circular and triangular ganglia, distributed at random in the submucous layer (Fig 1).

\section{Quantitative analysis}

The total ganglion number estimated in both age 

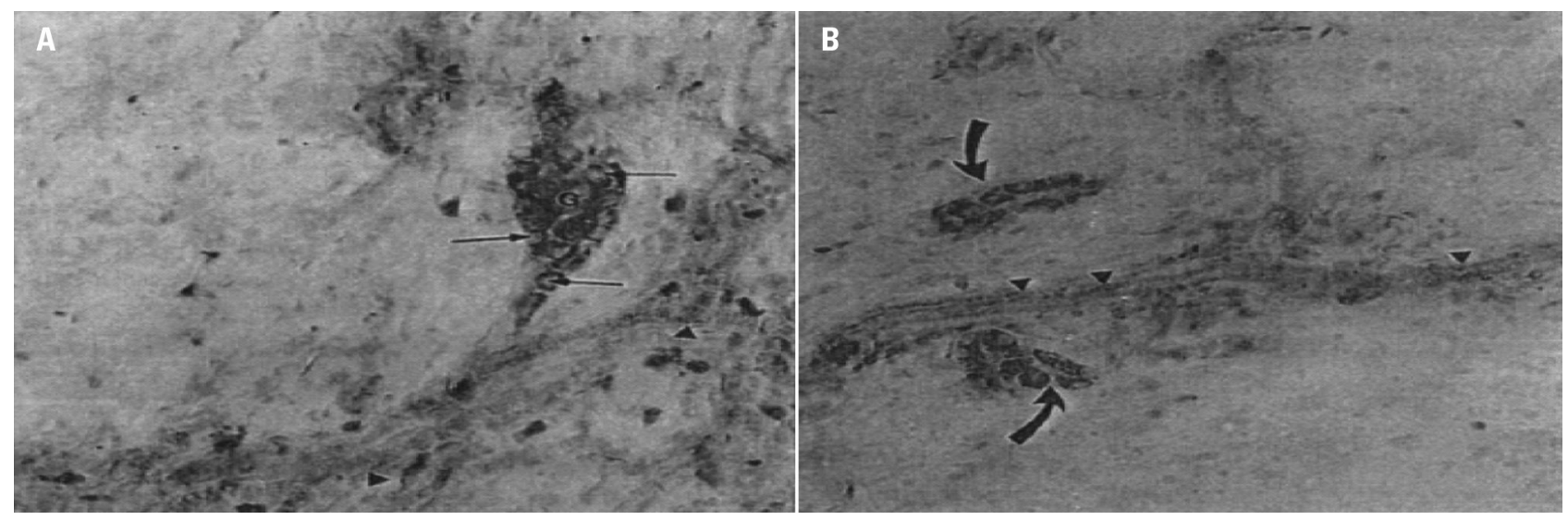

Fig 1. Preparations of the jejunum-ileum membrane of the guinea pig. [A] Ganglion of the submucous plexus (jejunum), triangular in shape of the young guinea pig (G), with compacted neurons (arrows). [B] Ganglion (jejunum) of old guinea pigs showing sparsely arranged neurons (curve arrows). Giemsa (A,B-256×).

Table 1. Mean values and standard deviations of the total number of ganglions of the jejunum-ileum of six guinea pigs in the two age groups.

\begin{tabular}{lcc} 
& \multicolumn{2}{c}{ Jejunum-ileum } \\
\cline { 2 - 3 } Age group & Total number & $\begin{array}{c}\text { Density of ganglia } \\
\text { (ganglia/(cm }{ }^{2} \text { ) }\end{array}$ \\
\hline Young & $90472 \pm 7748.8$ & $551 \pm 36.89$ \\
Old & $70103 \pm 1653.2$ & $413 \pm 11.86$ \\
\hline${ }^{*} \mathrm{p}=0$ & &
\end{tabular}

groups demonstrated a variation between 80227 ganglions and 99489 ganglions in young animals, and a variation between 67933 ganglions and 72724 ganglions in old animals. The ganglia of the jejunum-ileum of the young animals showed between 1 and 30 neurons with an average of $9 \pm 0.67$ neurons/ganglion. On the other hand, the ganglia of the old animals presented between 1 and 30 neurons with an average of $7 \pm 0.32$ neurons/ganglion. The average density of ganglia per $\mathrm{cm}^{2}$ in the young jejunum-ileum was of $551 \pm 36.89$ and in the old one it was of $413 \pm 11.86 / \mathrm{cm}^{2}$. For the density of neurons, $5011 \pm 291.11$ neurons $/ \mathrm{cm}^{2}$ were observed in the jejunum-ileum of young animals and $2918 \pm 120.70$ neurons $/ \mathrm{cm}^{2}$ in the old. The statistic comparison of the density of neurons and the total number of neurons both in the jejunum segments and ileum both separately and together, showed significant differences in the two segments of the small intestine (jejunum and ileum separately and together), between the young and old groups (Tables 1 and 2).

With regard to the size (area of the cellular profile), the neuron population of the submucous plexus of the guinea pig's small intestine is not even. In the young animals, the size of the neurons varied between $76 \mu \mathrm{m}^{2}$ and $704 \mu \mathrm{m}^{2}$ with an average of $253 \pm 0.141 \mu \mathrm{m}^{2}$ and in the old
Table 2. Mean values and standard deviations of the total number of neurons of the jejunum-ileum of six guinea pigs in the two age groups.

\begin{tabular}{lcc} 
& \multicolumn{2}{c}{ Jejunum-ileum } \\
\cline { 2 - 3 } Age group & Total number & $\begin{array}{c}\text { Density of neurons } \\
\text { (neurons } / \mathrm{cm}^{2} \text { ) }\end{array}$ \\
\hline Young & $818362 \pm 60998.6$ & $5011 \pm 291.11$ \\
Old & $493924 \pm 27039$ & $2918 \pm 120.70$ \\
\hline * & &
\end{tabular}

Table 3. Mean values and standard deviations of the neuron size (area of the cellular profile) of the jejunum-ileum $\left(\mu \mathrm{m}^{2}\right)$ in six guinea pigs in the two age groups.

\begin{tabular}{cc}
\hline Age group & Area of the cellular profile $\left(\mu \mathrm{m}^{2}\right)$ \\
\hline Young & $253 \pm 0.141$ \\
Old & $262 \pm 7.990$ \\
\hline
\end{tabular}

${ }^{*} p=0.172$

animals there was a variation between $87.5 \mu \mathrm{m}^{2}$ and 664 $\mu \mathrm{m}^{2}$ with an average of $262 \pm 7.990 \mu \mathrm{m}^{2}$ (Table 3).

This same variation average was confirmed when the jejunum and ileum segments were analyzed separately. There was no significant difference in the size of the neurons between the age groups, but an apparently higher quantity of collagen fibers in the individuals of the old group (Fig 2) than in the young animals was revealed by the light microscope with the Picrossirius technique.

\section{Ultrastrutural analysis}

The analysis of the electronmicrographs showed that there was apparently a larger number of mitochondria in the group of old animals, denoting degenerative aspects (Fig 3). It can be summarized in the presence of vacuol- 

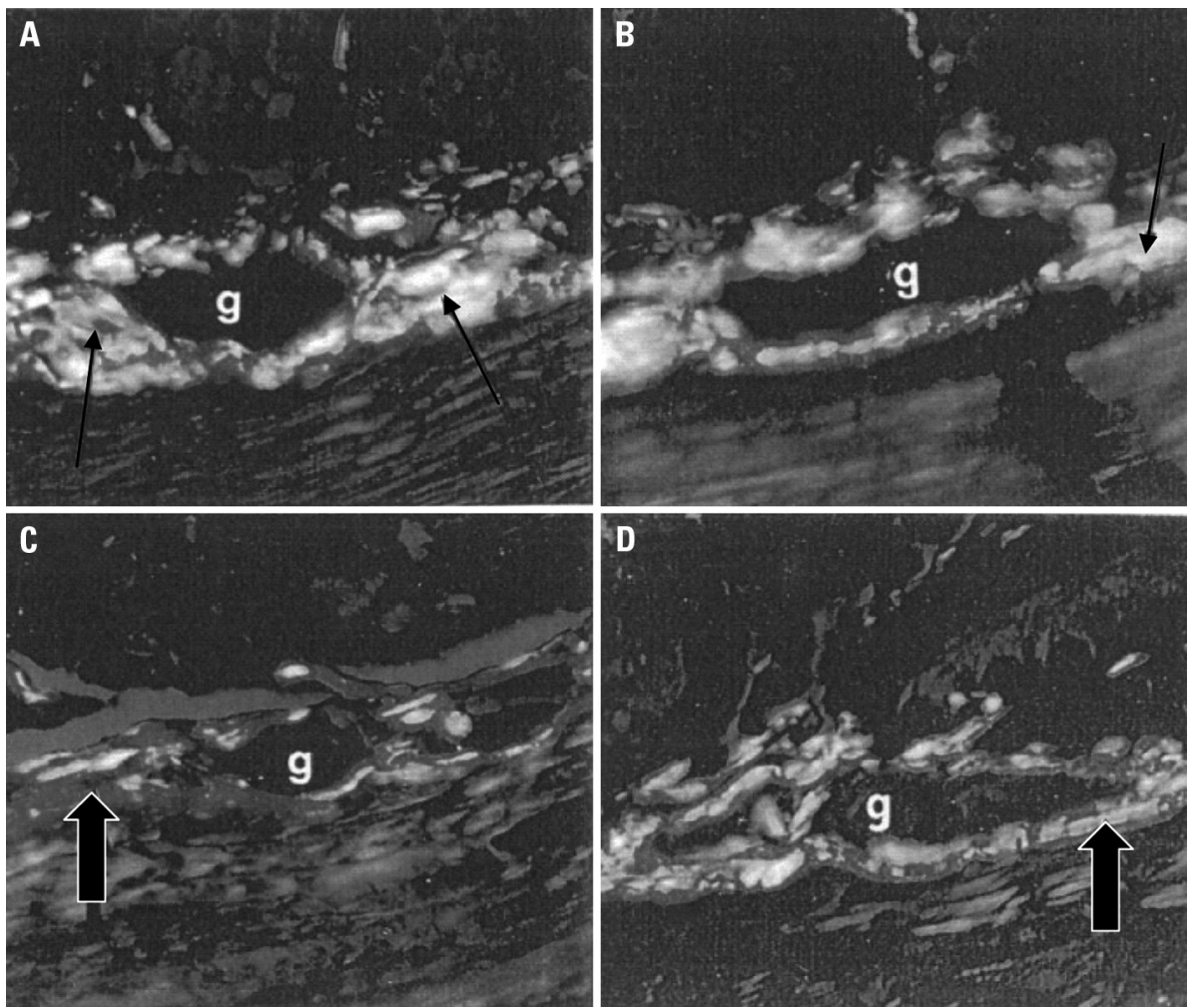

Fig 2. Transversal histological cuts to the jejunum-ileum of the guinea pig passing through the submucous ganglions (g). In $[A, B]$ the ganglion of the young jejunum surrounded by collagen fibers type I (narrow arrows). In $[C, D]$ the ganglion of old jejunum surrounded by collagen fibers type I (wide arrows) - polarized light $-[A, B, C, D-670 \times)$.
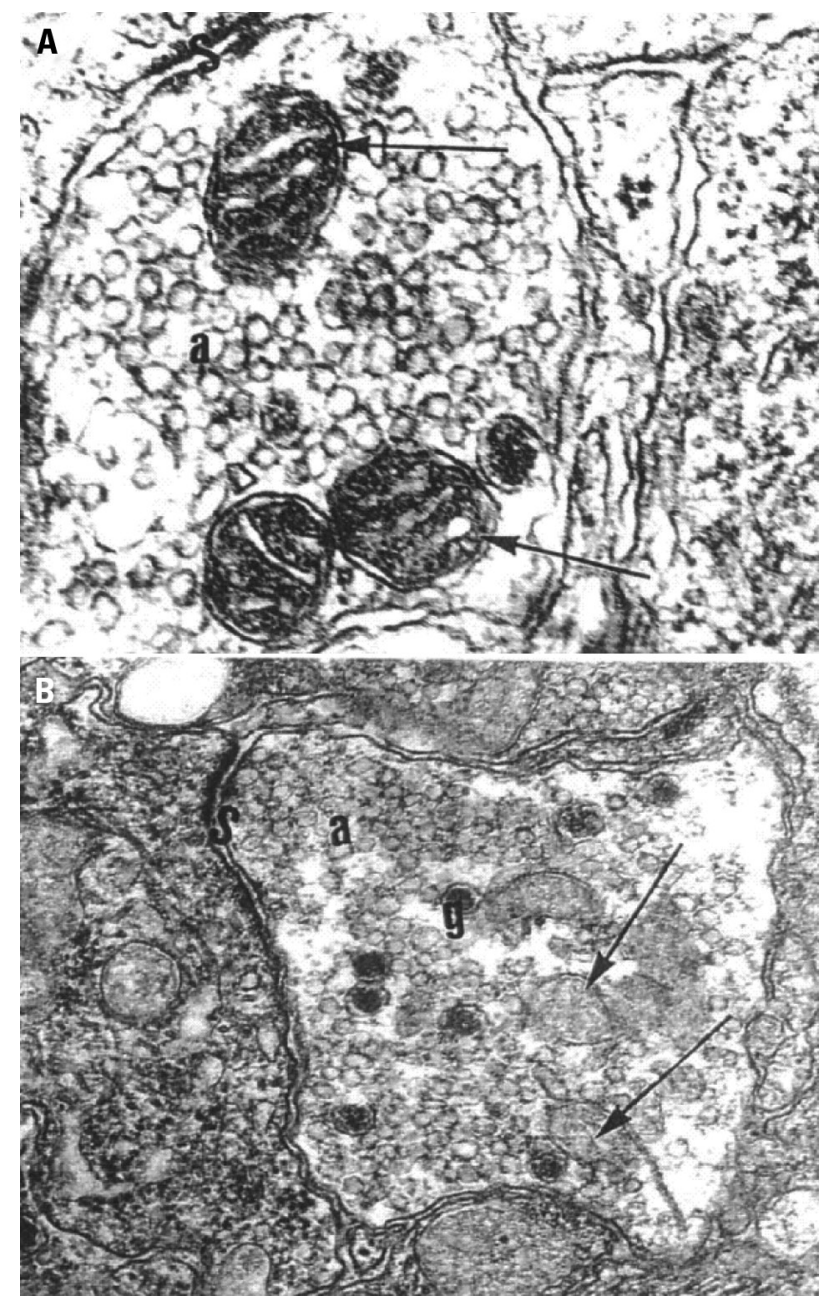

ized mitochondrias and difference in the number of granular and agranular synaptic vesicles.

\section{DISCUSSION}

The results of this work about the morphology of the neurons of the submucous plexus through the use of the staining techniques applied to the membrane preparations, confirm observations made by other authors using histological sections ${ }^{11-13}$. The neurons of this plexus in the jejunum-ileum of the guinea pig are mostly found in ganglion groups. They can also appear isolated or in pairs. These observations are in agreement with the findings of other authors in this species and also in others (Calomys callosus; newborn and adult rat) ${ }^{13-15}$.

The ganglia of the submucous plexus present small, medium and large sizes, containing a varied number of neurons, and arranged at random along the intestine, generally located close to blood vessels, with round, oval, triangular or elongated shapes confirming findings of other authors ${ }^{13,16}$. Apparently aging did not influence the morphology of the neurons, which was similar be-

Fig 3. Electronmicrography of a ganglion of the submucous plexus of the jejunum-ileum of the guinea pig. In $[A]$ in the young jejunum, mythocondrias (arrows) within the nervous termination, agranular vesicles (a) and synapse (S) can be observed. In [B] in the old jejunum, degenerated mythocondrias (arrows) can be observed. MET_ [A] $100000 \times ;[B] 80000 \times$. 
tween young and old animals. However, in ganglia of old animals, areas without neurons are sometimes observed, making up "clear" spaces inside of the ganglia similar to those found by Alves ${ }^{17}$, in the myenteric plexus of the colon of old guinea pigs. According to this author, this aspect is due to the loss of neurons in the ganglia.

Structurally comparing the submucous plexus of the jejunum-ileum of old animals with that of the young animals, in the old group there is apparently a capsule of more compact collagen fibers, with an intense red color indicating the presence of a higher number of type I collagen fibers around the ganglion. This is a practical general process that occurs in all organs, by the substitution of cells, in this case, nervous cells, by collagen fibers.

According to Moratelli, ${ }^{18}$ and Gomes et al. ${ }^{19}$, in the case of myenteric ganglia, the collagen fibers of the ganglia could act as protective elements for the ganglia and nervous fibers, preventing excessive distensions during the movements of the intestine. However, with aging, the increase of these fibers in the ganglia could damage its function, for example, making the metabolic exchanges between the capillary and the neurons of the ganglia difficult. This same reasoning could be applied to the ganglia of the submucous plexus.

The ultrastructure of the ganglia and neurons of the submucous plexus of the guinea pig's jejunum-ileum appeared similar to that of other species, both mammals, bullocks and fish, such as trout ${ }^{20,21}$. As Wilson et al. ${ }^{22}$, we also observed that in young adult guinea pigs, the ganglia are surrounded by a continuous basal sheet, without changes with aging. Also as these authors, we did not find other kinds of cells or blood vessels within the ganglia of the plexus of guinea pigs, except the neuronal cells, the Schwann cells and a neuropilus formed by the prolongation entanglement of the neurons and the neuroglial cells.

There are few findings on the ultrastructural aspects of aging, both in the myenteric and the submucous plexus. A work carried out by Gabella ${ }^{1}$ describes that degenerative signals are not common in the myenteric neurons in the aging process, showing that the ganglia keep the structures apparently well preserved in aged individuals. As Gabella ${ }^{1}$, we also found few degenerative changes with the transmission electron microscopic which can be summarized in the presence of vacuolized mitochondrias and difference in the number of granular and agranular synaptic vesicles. However, other works must be carried out, including the use of immunohistochemical techniques to detect aging changes in neurotransmissors of the submucous plexus.

With regard to the quantitative aspects, there is a lower density of ganglia in the jejunum-ileum of the old group. These results show a ganglion drop of about 20\% for the submucous plexus of the jejunum-ileum of old an- imals $(\mathrm{P}<0.05)$. The neurons of the jejunum-ileum of the animals of the old group presented a more sparse distribution within the ganglia, which confirms that the ganglia of the plexus contained fewer neurons.

There was an important decrease in the number of neurons of the submucous plexus of the jejunum-ileum of animals in the old group. The drop was about $38 \%$ compared to the plexus of the animals of the young group. This result is similar to the data obtained by Philips $^{7}$, who studied the aging of this plexus in the large intestine of rats.

Comparing our results with those regarding the aging of the myenteric plexus both in the small intestine and in other parts of the digestive tract, we confirmed a reduction between 20 and $60 \%$ in the number of neurons for the myenteric plexus both in humans, ${ }^{2-5}$ and in animals ${ }^{1,17,23,24}$. Therefore, the behavior of the submucous plexus follows a standard similar to that of the myenteric plexus with regard to aging.

According to Gabella ${ }^{11}$, the loss of neurons of the myenteric plexus of the small intestine of the guinea pig was of 40 and $60 \%$. On the other hand, for the human esophagus, Koberle ${ }^{26}$ and Wada ${ }^{27}$ observed a neuronal reduction of about $55 \%$ in the myenteric plexus due to age which would be responsible for malfunctions in the esophagus confirmed in the presbiesophagus. In a work on the aging of the myenteric plexus of the guinea pig colon, Alves ${ }^{17}$ observed a neuronal drop of around $46 \%$. Santer and Bak$\mathrm{er}^{25}$ observed a reduction of $64 \%$ in the rat colon for myenteric neurons. According to these authors, the neuronal loss that occurs in aging promotes a reorganization of the remaining neuronal elements, suggesting that this loss cannot be considered a degenerative process.

Histophysiological studies on the submucous plexus show that it is involved in the control of the contractile activity of the smooth musculature within the villi, coordination of intestinal motility, control of electrolytes, transport of ions and contains sensitive integrating elements and motors of the secretory activity of several cell $^{6-8}$. As we observed in this study, there was a significant loss of nervous cells of the submucous plexus, with aging, which is possibly related to the functional alterations such as atrophy of the mucous, diverticulosis or interference in the absorption of nutrients in the small intestine in the aged.

\section{REFERENCES}

1. Gabella G. Fall in the number of myenteric neurons in aging guinea pigs. Gastroenterology 1989;96:1487-1493.

2. Anaruma CA. Estudo morfoquantitativo do plexo mientérico do estômago humano em indivíduos jovens e idosos. [Tese de Doutorado - Instituto de ciências Biomédicas da Universidade de São Paulo] São Paulo, 1994.

3. De Souza RR, Moratelli HB, Borges N, Liberti EA. Age-induced nerve cell loss in the myenteric plexus of the small intestine in man. Gerontology 1993;39:183-188. 
4. Gabella G. The Number of neurons in the small intestine of mice, guineapig and sheep. Neuroscience 1987;22:737-752.

5. Meciano Filho J, Carvalho V C, De Souza RR. Nerve cell loss in the myenteric plexus of the human esophagus in relation to age: a preliminary investigation. Gerontology 1995;41:18-21.

6. Furness JB, Costa M. The enteric nervous system. New York, Churchil Livingstone, 1987

7. Philips RJ, Pairitz JC, Powley TL. Age-related neuronal loss in the submucosal plexus of the colon of Fischer 344 rats. Neurobiol Aging 2006;28: 1124-1137.

8. Stach W, Scheuermann DW. Concentration of external noradrenergic axonal nebwarks in the area of type III neuronal aggregates and dense capillary nebworks of the external submucosal plexus (Schabadasch) in the guineapig small intestine. Z Mikrosk-Anat Forsch 1985;99:617-626.

9. Barbosa AJ. A técnica histológica para gânglios nervosos intramurais em preparados espessos. Rev Bras Pesq Med Biol 1978;11:95-97.

10. Junqueira LCU, Cossermelli WS, Brentani RR. Difierencial staining of collagens type, I,II and III by Sirius red and polarization microscopy. Arch Histol Jpn 1978;41:267-274.

11. Gabella G. Innervation of the gastrointestinal tract. Int Rev Cytol 1979;59: 129-193.

12. Meissner G. Uber die nerve der karmwand. Z Ration Med N F 1857:8:364366; apud Furness, 1. B \& Costa, M. 1987.

13. Sousa NB, Libertl EA, De Souza RR. Estudo Morfoquantitativo, histoquímico e ultraestrutural do plexo submucoso do tubo digestivo do calomys callosus. [Tese de Doutorado - Universidade São Paulo] São Paulo, 1994.

14. Gabella G. Neuron size and number in the myenteric plexus of the newborn and adult rat. J Anat 1971;109:81-95.

15. Gunn M. Histological and histochemical observation on the myenteric and submucous plexuses of mammals. J Anat 1968;102:223-239.

16. Ohkubo K. Studies on the intrinsic nervous system of the digestive tract. I the submucous plexus of guinea Pig. JPN Med Sci 1936;6:1-20
17. Alves N. Estudo morfoquantitativo do envelhecimento no plexo mientérico do colo da cobaia. [Tese de Doutorado - Escola Paulista de Medicina] São Paulo, 1996

18. Moratelli HB. Estudo morfológico e quantitativo do plexo mientérico do intestino delgado humano em adultos e idosos. [Tese de Doutorado - Universidade São Paulo] São Paulo, 1990.

19. Gomes OA, de Souza RR, Liberti EA. A preliminary investigation of the effects of aging on the nerve cell number in the myenteric ganglia of the human colon. Gerentology 1997:43:210-217.

20. Ezeasor DN. Ultrastructural observation on the submucous plexus of the large Intestine of the raimbow trout (salmo gairdneri Rich). Z Mikrosk Anat Forsch Leipzig 1979;93:803-812.

21. Mann Von A, Pospischil A, Dahme E. Der plexus submucosus (Meissner) beim kalb. I. Licht and elektronenmikrospische untersuchung der nermalstruktur. Zentralbl Veterinaermed Rihe A 1984;31:585-600.

22. Wilson AJ, Furness JB, Costa M. The fine structure of the submucous plexus ofthe guinea-pig ileum II. Description and analysis of vesiculated nerve profiles. J. Neurocytol 1981;10:785-804

23. De Souza RR, Ferri S, Ferraz De Carvalho CA, Paranhos G. Myenteric plexus in a fresh water teleost intestine. Quantitative study of nerve cell. Anat Anz 1982;152:359-362.

24. Liberti EA, Queiroz LM, Pompeu E, et al. A quantitative and comparative study of the ganglionic neurons in the myenteric and submucous plexuses of the small intestine, and in the intramural plexus of the gall bladder of the guinea-pig. Rev Bras Cienc Morfol 1994;12:106-114.

25. Santer RM, Backer DM. Enteric neuron numbers and sizes in Auerbach's plexus in the small and large intestine of adult and aged rats. J Auton Nerv Syst 1988;25:59-67.

26. Koberle F. Patogenia do megaesôfago brasileiro e europeu. Rev Goiana Med 1963;9:79-116.

27. Wada MLF. Estudo quantitativo dos neurônios ganglionares do esôfago humano em relação à idade. Rev Goiana Med 1981;27:7-33. 